\title{
The Philosophical Basis of the Competence to Adjudicate Bankruptcy Cases Involving an Arbitration Clause
}

\author{
Bayu Adhypratama $^{1 *} \quad$ Suharingsih $^{2} \quad$ Sihabudin $^{3} \quad$ Abdul Rachmad Budiono ${ }^{2}$ \\ 1.Doctorate Candidate of Law Faculty, Brawijaya University, M.T. Haryono No. 169, Malang, Indonesia, 65145 \\ 2.Professor of Civil Law, Brawijaya University, M.T. Haryono No. 169, Malang, Indonesia, 65145 \\ 3.Doctorate of Law Faculty, Brawijaya University, M.T. Haryono No. 169, Malang, Indonesia, 65145
}

\begin{abstract}
This research stems from the conflict of competence between Commercial Court and Arbitration in a bankruptcy case involving an arbitration clause. This occurs when parties make an agreement including arbitration as a mechanism of dispute resolution. Nevertheless, when a dispute occurs, one of the parties file a bankruptcy petition to Commercial Court as contained in Article 303 of the Bankruptcy Law. Meanwhile, according to Article 3 and 11 of the Arbitration Law, agreements containing arbitration clause as a mean of dispute resolution provides absolute competence, which is consistent with the pacta sunt servanda principle outlined by Article 1338 of the Civil Code. This raises the question of whether Article 303 of the Bankruptcy Law is inconsistent with pacta sunt servanda or to the arbitration clause as the agreed mechanism of dispute resolution by the parties, because the substance of legal norms has philosophical basis. This research uses normative juridical approach which examines legal materials through the study of documents or library materials. The research show that Commercial Court is an extra ordinary court which settle bankruptcy filed to the court. Therefore, the competence cannot be set aside by arbitration in the sense of its legal position and capacity as extra judicial even though it originates from an agreement containing arbitration clause. The philosophical basis that can be applied in the conflict of law refers to the principles governing legislation, namely lex specialis derogat legi generalis, lex posterior derogat legi priori, and integration principles of Article 303 of the Bankruptcy Law.
\end{abstract}

Keywords: Arbitration, Bankruptcy, Commercial Court, Competence, Philosophical Basis.

DOI: $10.7176 / \mathrm{JLPG} / 107-09$

Publication date:March $31^{\text {st }} 2021$

\section{Introduction}

The development of economy and trade in the current era of globalization is increasing rapidly, including in the world of business. In the business world, it is common for individuals or companies to make loans in other businesses so that their business can survive in the midst of an increasingly fierce competition. When a company experiences a loss, one way to maintain its business is by the company (debtor) making loans to the other parties (creditors) to acquire a capital loan in the form of money or goods. The payment of debt by the creditor to the debtor is based on the view that the creditor trusts the debtor that payment shall be given on the time agreed. Additionally, the number of creditors who provide loans to debtors depends on how much capital is given and whether or not the capital is needed by the debtors.

Problems between debtors and creditors then arise regarding the repayment of debts that are due. The issue of the payment of debt can be resolved through various mechanisms or settlement methods adopted by debtors and creditors. In the initial process for the occurrence of debt-receivables, debtors, in engaging in a relationship with creditors, enters into an agreement with the creditor regulating the rights and obligations of both parties. Contained in the agreement is the dispute resolution mechanism if a dispute arises concerning the contents of the agreement, one of which is related to the debts that are due. The mechanisms of business dispute resolution can be differentiated into two, namely:

- The Litigation Mechanism is a dispute settlement mechanism the court using a legal approach through the authorized law enforcement officers or institutions in accordance to the applicable laws

- The Non-litigation Mechanism is a dispute settlement mechanism other than the court, such as conciliation, negotiation, settlement by custom, arbitration and alternative dispute resolution.

Therefore, the parties to the agreement can choose to settle the dispute through the litigation of nonlitigation mechanisms.

Generally, in the various agreements, dispute resolution related to the contents of the agreement is anticipated by the inclusion of a choice of law and choice of forum clauses in the agreement concerned. The choice of law clause refers to the law chosen or agreed upon by the parties to govern the agreement. As for the choice of forum, the parties shall agree upon which institution should settle the dispute, such as district court or arbitration, or through alternative dispute resolution by means of consultation, negotiation, mediation, conciliation, or expert assessment. The inclusion of choice of forum clause proves absolute competence to institution agreed upon. 
Usually in an agreement, the provisions regarding the dispute resolution have been agreed in writing. In practice, the dispute resolution that occurs can be carried out by the parties through court or arbitration, but currently the parties exercise arbitration as opposed to court as it is more beneficial for the parties due to its guaranteed confidentiality and a relatively shorter period of time. Other reasons include the fact that the process of dispute resolution by way of court is less attractive ass it takes a long time, costs more, and due to the procedural factors of the judicial system that are complex and complicated. This evident from the frequent inclusion of arbitration clauses as the dispute resolution mechanism when the parties make an agreement, not by court as the mechanism of dispute resolution. Thus, this has a legal consequence, that if the parties make an arbitration clause, it means that the parties have agreed in writing that if there is a dispute about the agreement, they will choose the mechanism of dispute resolution through arbitration and not submit a case before the court.

In accordance to Article 1 paragraph 1 of Law No. 30 of 1999 concerning Arbitration and Alternative Dispute Resolution (hereinafter referred to as Arbitration Law), arbitration is a way of resolving a civil dispute outside the general court based on an arbitration agreement made in writing by the disputing parties. The purpose of arbitration itself is to resolve disputes in the field of trade or business by the issuance of fast and fair binding decisions without complicated procedures or formalities that can hinder the settlement of disputes. However, sometimes the practice of dispute resolution by way of arbitration is not as smooth as expected. One of the problems arising from an agreement containing an arbitration clause is that if there is a dispute related to the bankruptcy case, who has the right or authority to resolve the dispute. On one hand, the parties agree to resolve the dispute through arbitration as agreed upon in the agreement, while on the other, if it is in the case of bankruptcy, the Commercial Court has the competence. Whereas the scope of the object of dispute through arbitration does cover all case but only disputes regarding trade and the rights which according to the laws and regulations are fully controlled by the disputing parties. Notwithstanding, it should be noted that if the dispute is primarily about bankruptcy, the settlement is under the competence of the Commercial Court, which is specifically part of the general court (District court). This is where the inconsistency or conflict of law occurs between the competence of the arbitration and the Commercial Court regarding the appropriate dispute resolution. In the end, the problem arises as to which institution actually has the competence to resolve bankruptcy cases that are bound by an arbitration agreement or clause.

The competence of the arbitration is regulated in Article 3 of the Arbitration Law which states that the District Court is not authorized to adjudicate disputes between parties bound by the arbitration agreement. This is further reinforced by Article 11 paragraph (1) of the Arbitration Law which states that the existence of a written arbitration agreement excludes the rights of the parties to submit for the settlement of dispute or conflict contained in the agreement to the District Court. In addition, Article 11 paragraph (2) of the Arbitration Law, the District Court is obliged to refuse and shall not interfere in the settlement of disputes that have been determined through arbitration, except in certain cases stipulated by this law. With these provisions it is concluded that dispute resolution through arbitration has absolute competence over dispute resolution through court. This suggests that any agreement that includes an arbitration agreement or clause made by the parties removes the competence of the general court (District Court). The legal consequences for the parties to the inclusion of an arbitration clause in an agreement is that when a dispute arises, it must be resolved through arbitration.

For the reasons above, a loan agreement containing an arbitration clause, in the event of a dispute concerning bankruptcy is the competence of the arbitration, not the Commercial Court on the basis that the Commercial Court is a specialized court established within the general court, thus part of the District Court. The Commercial Court is also not an independent court but rather a special court or a specialization from the general court environment because there are only four types of court recognized in Indonesia, namely the court of general jurisdiction, religious court, state administrative court and military court, pursuant to Article 25 of Law No. 48 of 2009 concerning Judicial Authority (hereinafter referred to as Judiciary Law). In the end, dispute resolution through arbitration as the agree choice of forum, will still cause problems if it is related to the absolute competence of the Commercial Court in bankruptcy cases.

Bankruptcy is the general confiscation of all assets of Bankrupt Debtor whose management and settlement are carried out by the Curator under the supervision of the Supervisory Judge. The legal instrument of bankruptcy in Indonesia is regulated in Law No. 37 of 2004 concerning Bankruptcy and Suspension of Payment (hereinafter referred to as Bankruptcy Law). An important aspect in improving bankruptcy regulations in Indonesia is the establishment of a Commercial Court as a specialized court within the scope of general court. Pursuant to Article 1 number (1) and Article 300 paragraph (1) of the Bankruptcy Law, the Commercial Court is competent to adjudicate bankruptcy voluntary petitions. Therefore, the Commercial Court is a special court established within the general court that has the competence to settle cases concerning bankruptcy and suspension of payment. Moreover, the Commercial Court is also competent to settle other commercial disputes such as in the field of Intellectual Property Rights (IPRs) and disputes in the bank liquidation process conducted by the Deposit Insurance Corporation (DIC).

The problem of the conflicting legal norms contained in the Bankruptcy Law and the Arbitration Law is the 
background to the cause of conflict of competence between the Commercial Court and Arbitration relating to a bankruptcy case that involves an arbitration clause. This is seen in Article 303 of the Bankruptcy Law which states that the court remains competent to adjudicate voluntary bankruptcy petitions from parties bound by the agreement which contain arbitration clauses, as long as the debt which forms the bases of the bankruptcy petition has met the provisions referred to in Article 2 paragraph (1) of this law. Article 303 of the Bankruptcy Law provides absolute competence to the Commercial Court in adjudicating bankruptcy cases that contain arbitration clauses; thereby excluding the competence of arbitration to resolve the dispute. However, the basic question arises on whether Article 303 of the Bankruptcy Law is contrary to the pacta sunt servanda principle, regarding the arbitration clause that has been agreed as the dispute resolution by the parties.

Moreover, the norming and embodiment of principles of law give absolute competence to the Commercial Court in the bankruptcy legal system in Indonesia or what is the philosophical basis or background for the formation of legal norms in Article 303 of the Bankruptcy Law. Generally, the formation of legal norms must contain a philosophical, sociological, and juridical foundation/basis. Meanwhile, the substance of legal norms has a philosophical basis in the form of principles of law. Whereas, the principle of law is an ideal element of law. Satjipto Rahardjo views that principles of law are the heart of legal regulations because principles of law are the broadest basis for the birth of legal regulations, and that legal regulations can ultimately be returned to these principles of law. Principles of law are also referred to as the reason for the birth of legal regulations or the ratio legis of legal regulations.

Nonetheless, in the development of law, legal conflicts regarding the competence between the Commercial Court and arbitration are still being debated and discussed to date as to which institution is more competent to settle bankruptcy cases involving arbitration clause. This existed due to several opinions, including the view that, according to Article 303 of the Bankruptcy Law, the Commercial Court still has the competency to adjudicate bankruptcy cases despite the involvement of an arbitration clause. Meanwhile, another opinion is of the view that if an agreement contains an arbitration clause, the Commercial Court is not competent on the grounds that the Commercial Court is a specialized court established within the General Court which is part of the District Court. While regarding the existence of debt in the concerned case, the settlement of dispute is held through arbitration. This is because on one hand, there is a provision in the Arbitration Law that negates the competence of the District Court, including the Commercial Court as part of the District Court. Meanwhile, on the other hand, the Bankruptcy Law also excludes the competency of arbitration with respect to a bankruptcy petition containing an arbitration clause. Article 303 of the Bankruptcy Law raises the question of whether the arbitration clause in an agreement will be set aside in the settlement of bankruptcy. The greater question is what are the philosophical or principles of law that derive the formation of theses legal norms. Concurrently, pursuant to Article 3 and Article 11 of the Arbitration Law, dispute resolution by way of an arbitration clause renders the arbitration the absolute competence. This is also reinforced by the pact sunt servanda principle recognized in Article 1338 of the Civil Code which explicitly states that an agreement made legally is binding for the parties.

The legal basis applied for absolute competence imperatively to the arbitration is based on the pacta sunt servanda principle as outlined by Article 1338 of the Civil Code. Thus, the arbitration has the capacity to resolve disputes arising from the agreement as an extra judicial as opposed to the District Court and hence the position of arbitration as extra judicial that emerged from the arbitration clause recognizes the legal effect that provides the arbitration the absolute competence to resolve disputes arising from the agreement. As stated above, arbitration removes the competence of the District Court to examine and settle disputes arising from an agreement containing an arbitration clause, including recourse to the Commercial Court, as is it stated the Commercial Court is part of the District Court so that the Commercial Court no longer has competence. Furthermore, the absolute competence of arbitration in resolving disputes bound by an arbitration clause can be seen in Article 3 and Article 11 of the Arbitration Law, which is the embodiment of the formation of legal norms from the pacta sunt servanda principle. Hence, the principles of pacta sunt servanda can be viewed as the ratio legis or basis of thought from the legal norms as regulated in the Arbitration Law.

Sudikno Mertokusumo views that principles of law are not concrete legal regulations, but rather basic ideas that are general in nature or are the root of concrete regulations contained in and behind every legal system that is incarnated in statutory regulations and court judgments which are positive law and can recognized through general interpretation in these concrete rules. The role of the science of law is to find this principles of law in positive law. Hence the principle of law is a concrete rule of law, but rather the general or abstract basis of concrete regulations. The principles of law also have an important role for the formation of law, the application of law, and the development of legal studies. For the formation of law, principles of law provide a basis of the provisions that need to be asserted in the rule of law. In the application of the law, principles of law are helpful for the use of interpretation and discovery of law and analogy. Meanwhile, for the development of legal studies, the principles of law are useful to which various rules of law can be shown which at a higher stage, are actually a unity. Therefore, the study of the principles of law has a very important value both for the academic world, lawmakers, and the practice of justice. 
Whereas, in the legal system there is no desire for conflict between elements or parts of the law. The legal system has consistently overcome this matter by providing legal principles. If there is a conflict of laws and regulations in the legal system, the principles of lex superior derogat legi inferior, lex posterior derogat legi priori and lex specialis derogat legi generalis are available. In the event of a conflict between statutory regulations and a court decision, the principle of res judicata pro veritate habetur is available (a judge's decision must be considered valid). The competence in resolving a dispute must of course follow the provisions or rules of law that apply in accordance with the applicable laws and regulations. Therefore, the study of the principles of law is very relevant in solving the conflict of competence between the Commercial Court and arbitration with the framework of the bankruptcy legal system in Indonesia.

The understanding of the existence of legal norms and why it is promulgated can be traced from its ratio legis, although the principles of law are not in it's the legal norms, no legal norms can by understood without knowing the principles of law contained within. Whereas, the provisions of statutory regulations must not contradict existing principles of law as it may be chaotic to the legal system. This is upheld so that the legal system can achieve legal objectives, including legal certainty, justice and benefit. For what is the point of the formation of law without an objective. As stated in Article 1 paragraph (3) of the 1945 Constitution of Indonesia, Indonesia is a Law State. Pancasila as the foundation of the State is the source of all sources that provides legal guidance and overcomes all statutory regulations including the 1954 Constitution. Hence, Pancasila is regarded as the foothold as well as the purpose of law. As a Law State that determined Pancasila as the philosophical foundation and the 1945 Constitution as the basis of the State, all regulations must be in conformity and sourced from Pancasila and the 1945 Constitution. Therefore, in the formation of a statutory regulation, it must consist a philosophical basis as a consideration or reason that illustrates that the regulations formed take into account the view of life, awareness and ideals of law which include the atmosphere and philosophy of the Indonesia nation originating from Pancasila and the Preamble of the 1945 Constitution.

In fact, the conflict of competence to adjudicate between arbitration and the Commercial Court arises as a result of one of the parties by including an arbitration clause in the agreement. Based on the arbitration clause agreed upon, both parties must submit the dispute to the arbitration not to the Commercial Court, should a dispute arise. But due to the reason of bankruptcy, one the parties may choose to settle the dispute to the Commercial Court. Hence the conflict of conflict of competence between arbitration and the Commercial Court. In the end, in refers back to the practice of law and the interests of the community in resolving disputes of the agreement concerned. The parties shall therefore comply on what has been agreed upon in the agreement as a form of legal awareness and legal compliance as these greatly determine the effectiveness of the implementation of law in society. Therefore, with the results of the study of the conflict of competence as stated above, the key answers can be found regarding the philosophical basis or principles of law of the formation of legal norms that render competence to upheld bankruptcy cases that are bound by arbitration clauses in the bankruptcy legal system in Indonesia.

From the description above, the issues to be examined and analyzed in this study are the philosophical basis for the competence of the Commercial Court in adjudicating a bankruptcy petition through an arbitration clause that does not breach the pacta sunt servanda principle in terms of the bankruptcy legal system in Indonesia. This study uses a normative juridical approach by using legal materials as the main source, while the method of collecting legal materials is by studying documents or library materials.

\section{Results and Discussion}

\subsection{Arbitration has Absolute Competence over District Courts}

Pursuant to Article II paragraph (3) of the 1958 New York Convention, it states: "the court of a Contracting State, when seized of an action in a matter in respect of which the parties have made an agreement within the meaning of article, shall, at the request of one of the parties refer the parties to arbitration. unless it finds that said agreement is null and void in operative or incapable of being performed". This article has placed the status of arbitration as a forum that has absolute competence to resolve and settle disputes, if the parties have made an agreement on that. Once the parties have made an agreement to settle the dispute through arbitration, then the arbitration has absolute competence to decide on disputes arising from the agreement concerned. Hence the reason why Article II paragraph (3) of the 1958 New York Convention recalls the official judiciary in each contracting state, in the form of a prohibition for the judicial institution to adjudicate a dispute if requested by a party, if it turns out that the dispute has been agreed to be resolved by arbitration. If a court then accepts a claim, when in fact the in applicant is bound by an arbitration clause, the court must declare that it is not competent to adjudicate. Notwithstanding, the court order that the dispute be resolve through an arbitration forum.

The absolute competence of arbitration to resolve disputes can only be waived by the court in the event that the arbitration agreement made by the parties is null and void, or that the agreement itself is impossible or inoperative incapable of being performed. Taking into account of Article II paragraph (3) of the 1958 New York Convention, the pacta sunt servanda principles lies implicit. According to the pact sunt servanda principle, 
every agreement made legally is binding as law for the parties. Thus, if in an agreement, the parties have bound themselves to resolve disputes arising from the agreement through an arbitration forum, the agreement is of absolute binding on them. At the same time, the parties have automatically rendered absolute competence to the arbitration to adjudicate disputes arising from the agreement.

Concerning the applicability of the arbitration clause as to whether its ca be waived by the bound parties, there consist of two school of thought in the theory of law:

\subsubsection{The Arbitration Clause is not of public order}

In the view that the arbitration clause is not of public order (niet ban openbaar orde), the arbitration clause does not absolutely remove the competence of the court to examine and adjudicate cases arising from the agreement. Although the agreement is accompanied by arbitration clause in the form of pactum de compromnittendo or a compromise deed, the District Court still has the competence to examine and adjudicate disputes arising from the agreement, if one of the parties submits a claim regarding this matter to the court. The parties can choose whether the dispute be submitted to arbitration or to the court. If one of the parties submits a dispute to arbitration, then the jurisdiction of the District Court is excluded. However, if one of the parties submits a dispute to the District Court, the competence of the arbitration will also be invalidated. Hence the extreme view that arbitration clauses are not of the capacity of being in the public interest (nonpublic order).

Apart from the extreme view above, some are somewhat lenient. A more lenient view, departed that the arbitration clause that is not absolute eliminates the competence of the court. This more lenient school of thought was implied in H. R.'s judgment dated January $8^{\text {th }} 1925$, which affirmed: an arbitration clause niet can openbaar order (not public order) hence disputes arising from an agreement containing an arbitration clause could still be submitted to a civil court; the court remains competent to examine and adjudicate the case as long as the opposing party does not file an objection regarding the arbitration clause in the dispute agreement; if no objection is filed, the opposing party is deemed to have waived its rights over the arbitration clause in question; Even if an objection is filed in a counterclaim, the Respondent is deemed to have waived his right to the arbitration clause, and the competence to adjudicate the dispute is excluded and is subject to the jurisdiction of the court.

\subsubsection{The Arbitration Clause as Pacta Sunt Servanda}

The term pacta derives from the Latin word pactum, which means agreement. From the term pactum, the phrase pacta sunt servanda was born, which developed and was adopted into a rule of law which implies: every legal agreement is binding on the parties or an agreement or promise must be kept, therefore the parties must comply with it. If the meaning of pacta sunt servanda, is associated to the provisions of Article 1338 of the Civil Code and to an agreement, there are several essential principles to be applied to determine the jurisdiction of arbitration: every agreement is binding on the parties, its binding power is similar to the power of law, and can only be withdrawn by mutual consent of the parties. As the arbitration clause is an agreement set forth by the parties in the agreement, the principles contained in proposition pacta sunt servanda and Article 1338 of the Civil Code, fully apply to the arbitration agreement. Reference of application:

- The arbitration consent is absolute binding on the parties,

- then if a dispute arises from what they have agreed to, the competence to resolve and settle the dispute, becomes the absolute competence of the arbitration.,

- hence the court is not competent to examine and adjudicate disputes in absolute,

- the waiver of the arbitration clause only occurs if it is expressly withdrawn at the consent of the parties, and

- that tacit withdrawal cannot be justified, let along unilateral withdrawal.

From the elaboration above, the principle of pacta sunt servanda is very contrary to the school of thought which considers arbitration clause not as public order (niet van opnebaa orde). In the school of thought of nonpublic order of arbitration clauses, withdrawal of arbitration clauses can be justified tacitly. It can even be withdrawn unilaterally by filing a claim to the court. If, however, of one the parties have filed a claim for the dispute to the court, and the opposing party does not file and objection, it is considered that the arbitration clause is void, and the competence to adjudicate the dispute that arises is the competence of the court. Meanwhile, the principle of pacta sunt servanda, since the parties are bound to the arbitration clause, the absolute competence of the arbitration applies to resolve disputes arising from the agreement. The waiver of absolute competence of the arbitration to resolve and adjudicate disputes arising from the agreement can only be justified if the parties agree to explicitly withdraw the arbitration clause. Therefore, whether or not an objection is filed, the court must comply with the provisions of Article $134 \mathrm{HIR}$ and declare that it does not have the competence to adjudicate.

In addition, there are several Supreme Court Jurisprudence which have confirmed that the existence of an arbitration clause eliminates the competence of the District Court to settle dispute, including:

- Supreme Court of Indonesia Decision Number: 455 K/Sip/1982 dated 27 February 1983; 
- $\quad$ Supreme Court of Indonesia Decision Number: 3179 K/Pdt/1984 dated 4 May 1988;

- Supreme Court of Indonesia Decision Number: 3190 K/Pdt/1995 dated 27 September 1996;

- Supreme Court of Indonesia Decision Number: 2424 K/Sip/1981 dated 22 February 1982;

- Supreme Court of Indonesia Decision Number: 225 K/Sip/1976 dated 30 September 1983;

- Supreme Court of Indonesia Decision Number: 1715 K/Pdt/2001 dated 12 December 2001;

Based on the jurisprudences mentioned, it can be concluded that by agreeing on the arbitration clause, the competence of arbitration has the capacity (legal capacity) to resolve disputes arising from the agreement in the position of being extra judicial as opposed to the District Court as an ordinary state court. Hence, the position of arbitration as extra judicial occurred from the arbitration clause has recognized the legal effect which gives absolute competence to the arbitration to resolve disputes arising from the agreement. The legal basis on which jurisprudence provides absolute competence imperatively to arbitration is based on the pacta sunt servanda principle stipulated in Article 1338 of the Civil Code.

The absolute competence of arbitration has also been clarified reaffirmed in Article 3 and 11 of the Arbitration Law which states that dispute resolution through arbitration has absolute competence over dispute resolution through the District Court. The rules in the Arbitration Law are a manifestation of the formation of legal norms from the principle of pacta sunt servanda. In conclusion, the principle of pacta sunt servanda is the philosophical basis or ratio legis of the absolute competence of arbitration against disputes containing clauses or arbitration clauses in the Arbitration Law. Therefore, every agreement that includes as arbitration clause agreed upon by the parties removes the competence of the District Court. In principle, the District Court does not have the competence to adjudicate a dispute when the parties have agreed to resolve the dispute through arbitration.

\subsection{The Application of the Principle of Integration Provides a Philosophical Basis of Absolute Competence of} Commerical Courts in the Bankruptcy Law System of Indonesia

The principles of integration as one of the principles in the bankruptcy legal system has a relation with other bankruptcy law principles that build the national bankruptcy law system, complement each other for the implementation of the principle of integration. As Sudikno Mertokusumo states, the legal system is a complete order or unit consisting of parts or elements that are closely related to one another, which are rules or statements about what should be, so that the legal system is a normative system. In other words, the legal system is a group of elements that exist in interaction with each other as an organized unit and cooperates towards the objective of unity. Furthermore, Sudikno Mertokusumo further explained that the system exists in various stages. The entire national placement of law can be regarded as the national legal system, as the civil law system, the criminal law system and constitutional law system are still recognized. There are systems, sub systems, sub-sub systems, and so on. Systematization is a tool for tracking legal institutions, with the system making it easier for the outlines in law. The system also allows finding and filling the absence of law in a simple way. If a certain event is not reckoned under a legal regulation, the solution must take into account whether there is inconsistency within the statutory system.

With the establishment of Pancasila as the ideals of law and at the same time as the fundamental norms of the state, the system of law of Indonesia in its formation, application and enforcement shall hold the values of Pancasila as the ideals of law that is constitutive and regulative and through the provisions of Pancasila as a highest norm that determines that basis for the legitimacy of a legal norm in the system of law of Indonesia. Gustav Radbruch emphasized that the ideal of law does not only function as a regulatory measure, which tests whether a positive law is fair or not, but also serves as a constitutive basis, which determines that without legal ideals, the law will lose its meaning as law. Therefore, in the formation of the Bankruptcy Law, it must also contain a philosophical basis which is a consideration or reason that illustrates that the regulations that are formed take into account the view of life, awareness, and legal ideals which include the mystical atmosphere and the philosophy of the Indonesian nation which originates from Pancasila and the Preamble of the 1945 Constitution.

The structure of the bankruptcy legal system is part of the legal system in Indonesia, which according to M. Yahya Harahap discusses the legal system, is only aimed to "review" the current system or to review the judiciary system, as well as in that purpose contains the intent and desire to improve the wheels of organization and the implementation of judicial functions (to improve the machinery of justice), so that a more effective and efficient legal system can be realized. The legal system in Indonesia is stated in Article 24 paragraph (2) of the 1945 Constitution which regulates the judicial power to be exercised by a Supreme Court and judicial bodies under it; general courts, religious courts, military courts, state administrative courts, and by a Constitutional Court. Furthermore, based on Article 8 paragraph (1) of Law No. 49 of 2009 concerning the Second Amendment to Law No. 2 of 1986 concerning General Courts states that in the domain of general courts, a special court can be established which is regulated by law. This means that there is a special court within the general court. A special court is a court that has the authority to examine, adjudicate and decide certain cases which can only be established in one of the judicial bodies under the Supreme Court as regulated by law, one of which is the 
Commercial Court which has the authority to adjudicate bankruptcy cases and suspension of payment obligations and other commercial matters, for example in the case of IPRs.

An important aspect in improving Indonesia's bankruptcy regulations is the establishment of a Commercial Court as a special court within the scope of general courts. The competence of the Commercial Court as a specific, substantive, and exclusive jurisdiction has been designed from the start to represent an expanded absolute competence, not only in bankruptcy and PKPU cases, but also includes the competence to adjudicate bankruptcy cases which contain arbitration clauses so that they reflect justice and legal protection for the parties. This can be seen in Article 303 of the Bankruptcy Law which states that the Commercial Court remains competent to examine and resolve bankruptcy petitions from parties related to the agreement containing arbitration clauses, as long as the debt on which the bankruptcy petition is based has met the provisions in Article 2 paragraph (1) of this law.

The solution to the problem of the legal conflict between the Bankruptcy Law and the Arbitration Law concerning the competence to adjudicate bankruptcy cases involving an arbitration clause is that the Arbitration Law only negates the competence of the District Court against disputes with arbitration clause so that the arbitration clause in an agreement is strictly obeyed by the parties, because in principle, it is binding on both parties or acts as law for both parties (principle pacta sunt servanda) and the District Court should not interfere with disputes subject to arbitration. Therefore, if there is a dispute whose agreement includes an arbitration clause, the District Court is obliged to refuse and does not have the competence to resolve the dispute. Meanwhile, bankruptcy disputes with arbitration clauses fall under the competence of the Commercial Court, which is part of the general court (District Court) as stipulated in the Bankruptcy Law.

This is also in line when referring to the application of statutory principles, namely the lex specialis derogat legi generalis principle (provisions that are specific in nature override general provisions). With the understanding that the Bankruptcy Law is a specific regulation (regarding bankruptcy even though it is bound by an arbitration clause), the Arbitration Law is set aside as a general rule. This is because in essence the Bankruptcy Law is a lex specialis derogat legi generalis that places bankruptcy cases in a special adjudication process. As such, the Commercial Court is an extra ordinary court that is specifically given the competence to examine and adjudicate a voluntary bankruptcy petition which can remove or eliminate the competence and position of arbitration as extra judicial even though it is bound by an arbitration clause. The application of the principle of lex specialis derogat legi generalis has also been emphasized in the bankruptcy case jurisprudence involving arbitration clauses which can be considered as a source of law on the basis that the Bankruptcy Law is a specialis law and arbitration provisions as general law so that specific provisions override provisions of a general nature.

Furthermore, relating to the existence of the principle of lex posterior derogat legi a priori (new legislation overrides old legislation) which means that old legislation and regulation on certain matters no longer apply when there is a new legislative rule and regulate such matters, even if the meaning and purpose are different or contrary to the old rules of law. The principle of lex posterior derogat legi a priori further clarifies the competence of the Commercial Court to be able to resolve bankruptcy matters even if there is an arbitration clause, so that the Arbitration Law becomes waived with the provisions of Article 303 of the Bankruptcy Law. Indeed, the Arbitration Law gives arbitration the competency in resolving disputes bound by arbitration clauses, but with the existence of Article 303 of the Bankruptcy Law as a new law of bankruptcy, it sets aside the provisions that are the absolute competence of arbitration in the Arbitration Law related to bankruptcy matters containing arbitration clauses. Therefore, in the event of a breach of agreement including a common debt dispute requiring compensation, the dispute may be settled through arbitration. However, if the debt dispute is filed with a bankruptcy petition, then it is the full competence of the Commercial Court. Thus, the absolute competence of the Commercial Court may override arbitration based on the principle of lex posterior derogat legi priori.

H. D. Stoud demonstrates an understanding of authority, that is, the entire rules that govern the use and acquisition of governmental authority by objects of public law in public legal relations. There are two elements contained in the understanding of the concept of authority presented by H. D. Stoud, namely the existence of the rules of law and the nature of legal relations. Before the authority is delegated to the institution that implements it, it must first be determined in legislation, whether in the form of laws, government regulations or lower-level rules. The nature of a legal relationship is a related nature and has a connection or bond or affiliation or is related to law. Whereas, some legal relationships are public and some are private.

In principle, authority is the power given to the state's tools to run the government. It can be concluded that the authority theory is a theory that analyzes and studies the power of government organs to exercise their authority both in the fields of public law and private law, in this case the authority between the Commercial Court and arbitration. The elements listed in the theory of authority include the existence of power, the existence of government organs, and the nature of their legal relationships. In connection with this Authority Theory, in essence, the existence of an arbitration clause does not prevent a debtor from being declared bankrupt, as long as the bankruptcy requirements specified in Article 2 paragraph (1) of the Bankruptcy Law have been fulfilled. 
Therefore, the Commercial Court still has the authority/competence to adjudicate bankruptcy cases which contain arbitration clauses as stipulated in Article 303 of the Bankruptcy Law. Even though the existence of an arbitration clause in an agreement, does not in itself cause the Commercial Court to not be authorized because basically no other judicial institution has the authority to try bankruptcy cases apart from the Commercial Court. Therefore, the Commercial Court has absolute authority or competence in the settlement of cases for a petition of bankruptcy, including those bound by an arbitration agreement or clause.

In addition, Article 303 of the Bankruptcy Law is a manifestation of the normalization of the principle of integration as stipulated in the General Understanding of Law No. 37 of 2004 which provides the basis for the absolute authority or competence of the Commercial Court to adjudicate bankruptcy cases containing arbitration clauses, and related to the legal consequences of bankruptcy decisions, also renders the competence to adjudicate the renvoi procedure, actio paulina, and other matters as referred to contained in Article 3 paragraph (1) of the Bankruptcy Law. The application of the principle of integration can be the basis for the realization of a national bankruptcy law that integrates civil procedural law, especially in the field of confiscation and execution under the absolute competence of the Commercial Court. The existence of the principle of integration provides a philosophical basis for the competence to adjudicate the Commercial Court as an extra ordinary court with legal instruments of legal status, legal power, and legal capacity, which are competent to receive, examine, and decide on the settlement of cases of bankruptcy petitions, including bankruptcy cases containing arbitration clauses and all civil case disputes relating to bankruptcy decisions. Because in essence, the meaning of the principle of integration in bankruptcy is a formal legal system and material law which is a unitary system of civil law and national civil procedural law. Therefore, the theoretical principle of integration is the answer to the problem of legal conflict regarding the dispute of competence between the Commercial Court and arbitration so that by realizing this principle of integration, it can guarantee that the bankruptcy legal system in Indonesia runs orderly and smoothly.

However, it is not correct to assume that Article 303 of the Bankruptcy Law overrides the application of the pacta sunt servanda principle in the settlement of bankruptcy cases containing arbitration clauses. The legal logic that can be understood is legal norms must follow the legal principles. Because the legal principle is a meta norm that must be used as a guideline for every statutory regulation so that it never leaves the application of the legal principle. This means that the existence of legal principles should give birth to legal norms which reflect the applicability of the legal principles. Hence, what should be adjusted is the legal norms, not the legal principles that must experience a degradation of values. Therefore, in principle, any legal norms should not conflict with applicable legal principles in order to create legal certainty. There is an opinion that has developed to date that the substance of the provisions in the Bankruptcy Law with the provisions contained in the Arbitration Law is out of sync and inconsistent, especially in relation to the competence of the Commercial Court in adjudicating bankruptcy cases which contain arbitration clauses deemed contrary to the application of the pacta sunt servanda principle. It is true that Article 303 of the Bankruptcy Law violates or contradicts the principle of pacta sunt servanda because the article is not guided by the pacta sunt servanda principle, but it is based on normalizing the principle of integration in the bankruptcy legal system in Indonesia.

The principle of integration provides a philosophical basis that bankruptcy is a formal legal system and material law which is a unitary system of civil law and national civil procedural law, thus making the unity of the Indonesian bankruptcy legal system under the absolute competence of the Commercial Court as a legal means of resolving debt problems fairly, promptly, openly and effectively as well as providing legal certainty and protection for debtors and creditors. Whereas Article 303 of the Bankruptcy Law is a legal norm created from the application of the principle of integration as stated in the General Understanding of the Bankruptcy Law, because in essence, every enforcement of statutory regulations must not deviate from the applicability of a legal principle. Therefore, it is the application of the principle of integration in the Bankruptcy Law that overrides or negates the application of the pacta sunt servanda principle within the scope of the bankruptcy legal system. The meaning and essence of the principle of integration is used as the basis for the consideration of lawmakers regarding bankruptcy to override the application of the pacta sunt servanda principle. In the bankruptcy law system in Indonesia, the principle of integration has clearly and firmly regulated the absolute competence of the Commercial Court in bankruptcy cases which contain arbitration clauses which refer to Article 303 of the Bankruptcy Law. Thus, the normalization of the principle of integration contained in the General Understanding of the Bankruptcy Law provides a philosophical basis for the Commercial Court as an extra ordinary court with special powers as specific, substantive and exclusive jurisdiction in the field of bankruptcy. This also as well as provides resolution of problems of legal conflict regarding disputes of competence between the Commercial Court and arbitration in bankruptcy cases which contain arbitration clauses which are a unitary system of civil law and national civil procedural law in guaranteeing an orderly bankruptcy legal system and specifically providing legal certainty for debtors and creditors to solve their debt problems fairly, promptly, openly, and effectively. 


\section{Conclusion}

Dispute resolution through arbitration based on Article 3 and Article 11 of the Bankruptcy Law as well as various jurisprudence of the Supreme Court have placed legal status and the competence of arbitration has legal capacity to resolve disputes arising from an agreement in an extra judicial position against a District Court based on the principle of pact sunt servanda stipulated in Article 1338 of the Indonesian Civil Code. In conclusion to that, the principle pacta sunt servanda is the philosophical basis or ratio legis for absolute competence of the arbitration against disputes containing clauses or arbitration agreements contained in the Arbitration Law. Therefore, any agreement that includes an arbitration agreement or clause made by the parties eliminates the authority of the District Court.

The philosophical basis that can be used in legal conflicts regarding disputes of competence between the Commercial Court and arbitration refers to the enactment of statutory principles namely lex specialis derogat legi generalis which bases on the Bankruptcy Law as a specific law and the Arbitration Law as a general law because in essence, the Bankruptcy Law places the bankruptcy cases in a special settlement process. Furthermore, with the enactment of the lex posterior derogate legi priori principle will further clarify the competence of the Commercial Court to be able to resolve the bankruptcy cases even though there is an arbitration clause therefore causing the Arbitration Law to be inapplicable with the existence of Article 303 of the Bankruptcy Law. In addition, Article 303 of the Bankruptcy Law is also a manifestation of norming the integration principle which provides a philosophical basis for the Commercial Court's authority to adjudicate as an extra ordinary court with legal status, legal power, and legal capacity, which is authorized to accept, examine, and decide the bankruptcy case settlement, including both bankruptcy case which contains an arbitration clause and all civil disputes related to a bankruptcy decision.

Article 303 of the Bankruptcy Law does not violate or contradict the principle of pacta sunt servanda because the article is based on the norming of the integration principle in the bankruptcy legal system in Indonesia. This integration principle makes the unity of the Indonesian bankruptcy legal system under the absolute competence of the Commercial Court as a legal means to resolve debt problems fairly, promptly, openly, and effectively as well as providing legal certainty and protection for debtors and creditors. Meanwhile, Article 303 of the Bankruptcy Law is a legal norm created from the enactment of the integration principle. Therefore, the application of the integration principle in the Bankruptcy Law overrides or negates the application of the pacta sunt servanda principle within the scope of the bankruptcy legal system in Indonesia.

\section{References}

Adolf, H. (2016), "Hukum Arbitrase Komersial Internasional”, Keni Media, Bandung.

Convention on the Recognition and Enforcement of Foreign Arbitral Award (Konvensi New York 1958).

Fuady, M. (2003), “Arbitrase Nasional Alternatif Penyelesaian Sengketa Bisnis”, Citra Aditya Bakti, Bandung.

Ridwan. (2008), "Hukum Administrasi Negara", RajaGrafindo Persada, Jakarta.

Salim. \& Nurbani, E.S. (2016), "Penerapan Teori Hukum Pada Penelitian Tesis Dan Disertasi", RajaGrafindo Persada, Jakarta.

Harahap, M.Y. (1997), "Beberapa Tinjauan Mengenai Sistem Peradilan Dan Penyelesaian Sengketa", Citra Aditya Bakti, Bandung.

Harahap, M.Y. (2001), “Arbitrase”, Sinar Grafika, Jakarta.

Hartini, R. (2009), "Penyelesaian Sengketa Kepailitan Di Indonesia (Dualisme Kewenangan Pengadilan Niaga Dan Lembaga Arbitrase)", Kencana, Jakarta.

Indonesia Civil Code.

Law of the Republic of Indonesia Number 15 of 2019 concerning Amendments to Law Number 12 of 2011 concerning the Formation of Laws and Regulations.

Law of the Republic of Indonesia Number 30 of 1999 concerning Arbitration and Alternative Dispute Resolution.

Law of the Republic of Indonesia Number 37 of 2004 concerning Bankruptcy and Postponement of Debt Payment Obligations.

Law of the Republic of Indonesia Number 48 of 2009 concerning Judicial Power.

Law of the Republic of Indonesia Number 49 of 2009 concerning Second Amendment to Law Number 2 of 1986 concerning General Courts.

Marzuki, P.M. (2016), "Penelitian Hukum", Kencana, Jakarta.

Mertokusumo, S. (2001), "Penemuan Hukum Sebuah Pengantar”, Liberty, Yogyakarta.

Mertokusumo, S. (2003), "Mengenal Hukum Sebuah Pengantar”, Liberty, Yogyakarta.

Presidential Decree of the Republic of Indonesia Number 34 of 1981 concerning Ratification of the Convention on the Recognition and Enforcement of Foreign Arbitral Award.

Rahardjo, S. (1985), "Ilmu Hukum”, Alumni, Bandung.

Shubhan, M.H. (2009), "Hukum Kepailitan: Prinsip, Norma Dan Praktik Di Peradilan”, Kencana, Jakarta.

Sidharta, B.A. (2015), "Refleksi Tentang Hukum Pengertian-Pengertian Dasar Dalam Teori Hukum”, Citra 
Aditya Bakti, Bandung.

Sinamo, N. (2009), "Metode Penelitian Hukum", Bumi Intitama Sejahtera, Jakarta.

Sjahdeini, S.R. (2016), "Sejarah, Asas, Dan Teori Hukum Kepailitan Memahami Undang-Undang No. 37 Tahun 2004 Tentang Kepailitan Dan Penundaan Kewajiban Pembayaran”, Kencana, Jakarta.

Soemartono, G. (2006), "Arbitrase Dan Mediasi Di Indonesia", Gramedia Pustaka Utama, Jakarta.

Sudiarto. (2015), "Negosiasi, Mediasi, \& Arbitrase Penyelesaian Sengketa Alternatif Di Indonesia", Pustaka Reka Cipta, Bandung.

Sutiyoso, B. (2006), "Penyelesaian Sengketa Bisnis: Solusi Dan Antisipasi Bagi Peminat Bisnis Dalam Menghadapi Sengketa Kini Dan Mendatang”, Citra Media Hukum, Yogyakarta. 